\title{
Front Matter: Volume 9111
}

, "Front Matter: Volume 9111," Proc. SPIE 9111, Ocean Sensing and Monitoring VI, 911101 (13 June 2014); doi: 10.1117/12.2072968

SPIE Event: SPIE Sensing Technology + Applications, 2014, Baltimore, MD, United SPIE. States 


\section{PROCEEDINGS OF SPIE}

\section{Ocean Sensing and Monitoring VI}

Weilin W. Hou

Robert A. Arnone

Editors

6-7 May 2014

Baltimore, Maryland, United States

Sponsored and Published by

SPIE 
The papers included in this volume were part of the technical conference cited on the cover and title page. Papers were selected and subject to review by the editors and conference program committee. Some conference presentations may not be available for publication. The papers published in these proceedings reflect the work and thoughts of the authors and are published herein as submitted. The publisher is not responsible for the validity of the information or for any outcomes resulting from reliance thereon.

Please use the following format to cite material from this book:

Author(s), "Title of Paper," in Ocean Sensing and Monitoring VI, edited by Weilin W. Hou, Robert A. Arnone, Proceedings of SPIE Vol. 9111 (SPIE, Bellingham, WA, 2014) Article CID Number.

ISSN: 0277-786X

ISBN: 9781628410488

Published by

SPIE

P.O. Box 10, Bellingham, Washington 98227-0010 USA

Telephone +1 3606763290 (Pacific Time) · Fax +1 3606471445

SPIE.org

Copyright (C) 2014, Society of Photo-Optical Instrumentation Engineers.

Copying of material in this book for internal or personal use, or for the internal or personal use of specific clients, beyond the fair use provisions granted by the U.S. Copyright Law is authorized by SPIE subject to payment of copying fees. The Transactional Reporting Service base fee for this volume is $\$ 18.00$ per article (or portion thereof), which should be paid directly to the Copyright Clearance Center (CCC), 222 Rosewood Drive, Danvers, MA 01923. Payment may also be made electronically through CCC Online at copyright.com. Other copying for republication, resale, advertising or promotion, or any form of systematic or multiple reproduction of any material in this book is prohibited except with permission in writing from the publisher. The CCC fee code is 0277-786X/14/\$18.00.

Printed in the United States of America.

Publication of record for individual papers is online in the SPIE Digital Library.

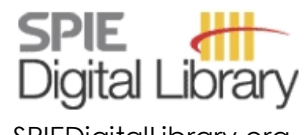

SPIEDigitalLibrary.org

Paper Numbering: Proceedings of SPIE follow an e-First publication model, with papers published first online and then in print and on CD-ROM. Papers are published as they are submitted and meet publication criteria. A unique, consistent, permanent citation identifier (CID) number is assigned to each article at the time of the first publication. Utilization of CIDs allows articles to be fully citable as soon as they are published online, and connects the same identifier to all online, print, and electronic versions of the publication. SPIE uses a six-digit CID article numbering system in which:

- The first four digits correspond to the SPIE volume number.

- The last two digits indicate publication order within the volume using a Base 36 numbering

system employing both numerals and letters. These two-number sets start with 00, 01, 02, 03, 04,

$05,06,07,08,09,0 A, 0 B \ldots 0 Z$, followed by 10-1Z, 20-2Z, etc.

The CID Number appears on each page of the manuscript. The complete citation is used on the first page, and an abbreviated version on subsequent pages. Numbers in the index correspond to the last two digits of the six-digit CID Number. 


\section{Contents}

vii Conference Committee

SESSION 1 OCEAN REMOTE SENSING

911102 Observations of ocean diurnal variations from the Korean geostationary ocean color imager (GOCl) [9111-1]

M. Wang, NOAA/NESDIS/STAR (United States); S. Son, L. Jiang, W. Shi, NOAA/NESDIS/STAR

(United States) and Colorado State Univ. (United States)

911103 Calibration uncertainty in ocean color satellite sensors and trends in long-term environmental records [9111-2]

K. R. Turpie, Univ. of Maryland, Baltimore County (United States); R. E. Eplee Jr., Science Applications International Corp. (United States); B. A. Franz, C. Del Castillo, NASA Goddard Space Flight Ctr. (United States)

911105 Sensitivity of calibration gains to ocean color processing in coastal and open waters using ensembles members for NPP-VIIRS [9 111 1-4]

R. Arnone, R. Vandermeulen, The Univ. of Southern Mississippi (United States); S. D. Ladner, U.S. Naval Research Lab. (United States); J. Bowers, P. Martinolich, QinetiQ North America (United States); G. Fargion, San Diego State Univ. (United States); M. Ondrusek,

NOAA/NESDIS (United States)

911106 VIIRS reflective solar bands calibration changes and potential impacts on ocean color applications [9 $1111-5]$

S. Blonski, Univ. of Maryland, College Park (United States); C. Cao, NOAA/NESDIS/STAR (United States); X. Shao, Univ. of Maryland, College Park (United States); S. Uprety, Colorado State Univ. (United States)

911107 Inter-satellite comparison and evaluation of Navy SNPP VIIRS and MODIS-Aqua ocean color properties [9111-6]

S. D. Ladner, U.S. Naval Research Lab. (United States); R. Arnone, R. Vandermeulen, The Univ. of Southern Mississippi (United States); P. Martinolich, QinetiQ North America (United States); A. Lawson, U.S. Naval Research Lab. (United States); J. Bowers, QinetiQ North America (United States); R. Crout, U.S. Naval Research Lab. (United States); M. Ondrusek, NOAA/NESDIS (United States); G. Fargion, San Diego State Univ. (United States)

911108 Evaluation of in-situ radiometric data processing for calibration and validation of satellite ocean color remote sensing [9111-7]

P. Naik, NOAA/NESDIS (United States) and Colorado State Univ. (United States); M. Wang, NOAA/NESDIS (United States) 
911109 Estimating sea surface salinity in coastal waters of the Gulf of Mexico using visible channels on SNPP-VIIRS [911 $11-8$ ]

R. A. Vandermeulen, R. Arnone, The Univ. of Southern Mississippi (United States); S. Ladner, U.S. Naval Research Lab. (United States); P. Martinolich, QinetiQ North America (United States)

9111 OA Relationship between sea surface salinity from L-band radiometer and optical features in the East China Sea [91 11 1-9]

B. Kil, The Univ. of Southern Mississippi (United States); D. Burrage, J. Wesson, U.S. Naval Research Lab. (United States); S. Howden, The Univ. of Southern Mississippi (United States)

9111 OB Reducing ocean surface specular reflection in WorldView-2 images [9111-10]

K. W. Patterson, U.S. Naval Research Lab. (United States)

SESSION 2 SENSING SEA SURFACE TEMPERATURE

9111 OC Sea-surface temperature from Suomi-NPP VIIRS: algorithm development and uncertainty estimation (Invited Paper) [91111-12]

P. J. Minnett, R. H. Evans, G. P. Podestá, K. A. Kilpatrick, Univ. of Miami (United States)

9111 OD Analysis of the VIIRS cloud mask, comparison with the NAVOCEANO cloud mask, and how they complement each other [9111-45]

J.-F. P. Cayula, QinetiQ North America (United States); D. A. May, B. D. McKenzie, Naval

Oceanographic Office (United States)

9111 OE SST algorithms in ACSPO reanalysis of AVHRR GAC data from 2002-2013 [9111-14]

B. Petrenko, NOAA/NESDIS/STAR (United States) and GST, Inc. (United States); A. Ignatov, NOAA/NESDIS/STAR (United States); Y. Kihai, NOAA/NESDIS/STAR (United States) and GST, Inc. (United States); X. Zhou, NOAA/NESDIS/STAR (United States) and Colorado State Univ. (United States); J. Stroup, NOAA/NESDIS/STAR (United States) and STG, Inc. (United States)

9111 OG Exploring pattern recognition enhancements to ACSPO clear-sky mask for VIIRS: potential and limitations (Invited Paper) [91 11 1-16]

I. Gladkova, NOAA/NESDIS/STAR (United States), GST, Inc. (United States), and City College of New York (United States); Y. Kihai, NOAA/NESDIS/STAR (United States) and GST, Inc. (United States); A. Ignatov, NOAA/NESDIS/STAR (United States); F. Shahriar, City College of New York (United States) and The Graduate Ctr., CUNY (United States); B. Petrenko, NOAA/NESDIS/STAR (United States) and GST, Inc. (United States)

SESSION 3 UNDERWATER IMAGING: SPECIAL SESSION DEDICATED TO WALTON MCBRIDE

$9111 \mathrm{OL} \quad$ Multistatic optical imaging system [9111-21]

D. Alley, B. Cochenour, A. Laux, L. Mullen, Naval Air Systems Command (United States)

iv 
$91110 \mathrm{M} \quad$ Experimental studies of the compressive line sensing underwater serial imaging system [91 11 1-22]

B. Ouyang, Florida Atlantic Univ. (United States); W. Hou, U.S. Naval Research Lab. (United States); F. R. Dalgleish, F. M. Caimi, Florida Atlantic Univ. (United States); G. Nootz, Naval Post Graduate School (United States); A. K. Vuorenkoski, Florida Atlantic Univ. (United States)

$91110 \mathrm{~N} \quad$ Underwater imaging of polarized targets [9111-23]

A. Gilerson, Y. Gu, C. Carrizo, A. Ibrahim, A. El-Habashi, R. Foster, The City College of New York (United States); P. Brady, M. E. Cummings, The Univ. of Texas at Austin (United States);

S. Ahmed, The City College of New York (United States)

911100 Overview of a hybrid underwater camera system [9111-24]

P. Church, Neptec Technologies Corp. (Canada); W. Hou, U.S. Naval Research Lab. (United States); G. Fournier, Defence Research and Development Canada, Valcartier (Canada); F. Dalgleish, Florida Atlantic Univ. (United States); D. Butler, S. Pari, M. Jamieson, D. Pike, Neptec Technologies Corp. (Canada)

9111 OP Waveform design considerations for modulated pulse lidar [9111-25]

S. O'Connor, R. Lee, L. Mullen, B. Cochenour, Naval Air Systems Command (United States)

\section{SESSION 4 LASER OCEAN SENSING}

$91110 R \quad$ Optical ranging techniques in turbid waters [9111-28]

D. W. Illig, W. D. Jemison, Clarkson Univ. (United States); R. W. Lee, A. Laux, L. J. Mullen, Naval Air Systems Command (United States)

9111 OT Optical remote sensing of sound in the ocean [9111-30]

J. H. Churnside, NOAA (United States); K. Naugolnykh, Zel Technologies, LLC (United States); R. D. Marchbanks, Univ. of Colorado at Boulder (United States) and NOAA (United States)

$91110 \mathrm{OU} \quad$ Beyond bathymetry: probing the ocean subsurface using ship-based lidars [9111-31]

C. C. Trees, Ctr. for Maritime Research \& Experimentation (United States)

\section{SESSION 5 OCEAN OBSERVATION}

$91110 \mathrm{Y}$ Validation of ocean color sensors using a profiling hyperspectral radiometer [9111-36] M. E. Ondrusek, E. Stengel, NOAA/NESDIS (United States); M. A. Rella, NATO Science and Technology Organization (Italy); W. Goode, S. Ladner, U.S. Naval Research Lab. (United States); M. Feinholz, Moss Landing Marine Labs. (United States)

\section{POSTER SESSION}

911110 Comparison of VIIRS SST fields obtained from differing SST equations applied to a region covering the northern Gulf of Mexico and western North Atlantic [9111-13] J.-F. P. Cayula, QinetiQ North America (United States); R. A. Arnone, R. A. Vandermeulen, The Univ. of Southern Mississippi (United States) 
911111 Underwater pressure measurement using fibre optic extrinsic Fabry-Perot interferometric (EFPI) sensors [9111-38]

D. B. Duraibabu, S. Poeggel, E. Lewis, T. Newe, Univ. of Limerick (Ireland)

911112 A model-based ELM for atmospheric correction over Case 2 water with Landsat 8 [9111-39] J. A. Concha, J. R. Schott, Rochester Institute of Technology (United States)

911113 The impact of turbulent fluctuations on light propagation in a controlled environment [9111-40]

S. Matt, National Research Council (United States); W. Hou, W. Goode, U.S. Naval Research Lab. (United States)

911114 Regional vicarious gain adjustment for coastal VIIRS products [9111-41] J. Bowers, QinetiQ North America (United States); R. Arnone, The Univ. of Southern Mississippi (United States); S. Ladner, U.S. Naval Research Lab. (United States); G. S. Fargion, San Diego State Univ. (United States); A. Lawson, U.S. Naval Research Lab. (United States); P. Martinolich, QinetiQ North America (United States); R. Vandermeulen, The Univ. of Southern Mississippi (United States)

911118 Algorithms for the remote estimation of chlorophyll-a in the Chesapeake Bay [9111-46] I. Ioannou, A. Gilerson, The City Univ. of New York (United States); M. Ondrusek, NOAA/NESDIS/STAR (United States); R. Foster, A. El-Habashi, K. Bastani, S. Ahmed, The City Univ. of New York (United States)

911119 Implications of a new phase function for autonomous underwater imaging [9111-47] G. R. Fournier, V. Sanjuan-Calzado, C. Trees, Ctr. for Maritime Research \& Experimentation (Italy)

Author Index 


\section{Conference Committee}

Symposium Chair

David A. Whelan, Boeing Defense, Space, and Security

(United States)

Symposium Co-chair

Wolfgang Schade, Technische Universität Clausthal (Germany) and Fraunhofer Heinrich-Hertz-Institut (Germany)

Conference Chairs

Weilin W. Hou, U.S. Naval Research Laboratory (United States)

Robert A. Arnone, University of Southern Mississippi (United States)

Conference Program Committee

Sam Ahmed, The City College of New York (United States)

James H. Churnside, National Oceanic and Atmospheric

Administration (United States)

Richard L. Crout, U.S. Naval Research Laboratory (United States)

Alexander Ignatov, National Oceanic and Atmospheric

Administration (United States)

Linda J. Mullen, Naval Air Systems Command (United States)

Mitchell A. Roffer, Roffer's Ocean Fishing Forecasting Service, Inc.

(United States)

Michael Twardowski, WET Laboratories, Inc. (United States)

\section{Session Chairs}

1 Ocean Remote Sensing

Sam Ahmed, The City College of New York (United States)

Robert A. Arnone, The University of Southern Mississippi (United States)

2 Sensing Sea Surface Temperature

Alexander Ignatov, National Oceanic and Atmospheric

Administration (United States)

3 Underwater Imaging: Special Session Dedicated to Walton McBride

Linda J. Mullen, Naval Air Systems Command (United States)

Weilin W. Hou, U.S. Naval Research Laboratory (United States) 
4 Laser Ocean Sensing

James H. Churnside, National Oceanic and Atmospheric

Administration (United States)

Weilin W. Hou, U.S. Naval Research Laboratory (United States)

5 Ocean Observation

Michael S. Twardowski, WET Laboratories, Inc. (United States) 